\title{
International Trade and Macro-Economic Policy in Eurasian Economies
}

\author{
Asst. Prof. Dr. Naime İrem Koşan (Beykent University, Turkey) \\ Prof. Dr. Sudi Apak (Esenyurt University, Turkey) \\ Prof. Dr. Selahattin Sarı (Beykent University, Turkey)
}

\begin{abstract}
International trade is defined the exchange of goods, services, and capital among various countries and regions. Also the potential of imports and exports account for an important part of growth. On the other hand, total value of international trade in goods and services shows the countries' integration into the world economy. In this paper we focused on to analyze the effects on imports and make inferences for Eurasian Countries.

In this paper we aim to examine the relationship between imports and macro-economic indicators in 6 Eurasian economies. To analyze the relationship, we used panel data regression analysis. Data obtained from World Bank. The panel data covers 1996-2012 periods and 6 countries which named Kazakhstan, Russian Federation, Uzbekistan, Kyrgyz Republic, Azerbaijan and Turkmenistan. We predicted pooled, fixed effects and random effects panel data models using the Stata and analyzed them. The dependent variable is defined the imports in our model. It has been found that gross domestic savings, foreign direct investments and, and exports are statistically significant for this countries.

The results found in this paper show that gross domestic savings has negative effects on imports. On the other hand, for this 6 countries foreign direct investments (inflow) and exports have positive effects on imports as we expected. It shows us the economic positions of Eurasian countries still depend on Russian Federation. Also, these findings have important policy implications for Eurasian Countries. Our interpretation of these findings is that, integration to world economy has generally positive effects on foreign direct investments for this countries.
\end{abstract}

\section{Introduction}

The analysis of foreign trade and macroeconomic policy has been a popular area of interest for a very long time.

The aim of the study is to propose policy making suggestions to the countries by examining macroeconomic variables that affect the imports. In this paper in order to examine the relationship between imports and macroeconomic indicators, panel data analysis has been used. The data covers 1996-2012 periods and 6 Eurasian economies. Data obtained from World Bank.

\section{Literature Review}

When we examine the studies related to the Eurasian economies, we observe that the studies are mostly related with gas trade, political processes in the region and assessment of such policies.

Hartwell (2013) had analyzed the customs union agreement signed between Belarus, Kazakhstan in 2012 and observed the opportunities for the region in his study. He examined and assessed the trade liberties of the countries in the Commonwealth of Independent States of Eurasian integration and as in conclusion, he stated that the trade between such states will be strengthened and this can be done with supportive policies and this is a great opportunity for these countries.

Mustafa (2013) has examined the Eurasianism concept in his study and analyzed the role of Kazakhstan within this concept. He further states that there are opportunities and challenges for the Eurasian union and political developments, organizational structures, and democratic processes are effective in such countries and nationalist movements in Russia, in particular, may be challenging.

Libman and Vinokurov (2012) analyzed the regional integration and economic convergence of the Soviet Union countries between 1999 and 2008 after the Soviet period. The countries such as Azerbaijan, Armenia, Kazakhstan, Kyrgyzstan, Tajikistan, Belarus, Georgia, Moldova, and Russia have had cluster analysis for trade integration, labor migration, and macroeconomic convergence variable. As a result of the study, they observed that integration highly depends on the geographical convergence and economic relations convergence depends on the domestic economy politics and economic growths of the country. However, it has been concluded that economic integration and relations of countries with each other are not affected by each other.

Kid (2007), has made a comparative analysis by examining the social variables such as macroeconomic and education for Central Asia. In its conclusion, it has been stated that there are opportunities in Asia and Maglev speed train network is significant for connection (via transportation) between the Central Asia and Eurasia countries to restructure the region. 
Norling and Swanstrom (2007) states that it is required to restructure the infrastructure decrease the inefficiency arising out of the customs and improve the cooperation in the region to assess the potential in the Eurasia continent. However, they state that the energy is an integral factor and brings together the region. They also stated that donor countries and international organizations can remove the trade barriers on energy and as a result the national income of Afghanistan and Central Asia could increase.

\section{Data Source}

Data set comprises 1996-2012 period of 6 Eurasian economies. Data of Azerbaijan, Russian Federation, Uzbekistan, Kazakhstan, Kyrgyz Republic and Turkmenistan are obtained from Worldbank. Imports is selected as dependent variable and Gross Domestic Savings, Foreign Direct Investments of countries and exports are selected as independent variables in the study. The import used as a dependent variable shows the share of all commodities and services that imported by the country within the GDP.

The export variable shows the share of all commodities and services exported by the country within the GDP.

Gross Domestic Savings is obtained by subtracting the final consumption expenditures from the Gross Domestic Product. Domestic savings is one of the most important variables when economy is analyzed in its entirety. According to the tendency to saving in a country, the rate of external savings to be made, the field where the investment will be made and the way of position to be taken in that country will be determined. In our study, the numbers of gross domestic savings are taken as the percentage in the gross domestic product.

Foreign direct Investments is the variable involving the equity and investments with long and short-term capital inflow in the balance of payment reported from the activities of the foreign investors. This variable is included in the model by proportioning to GDP such as other variables.

\section{Empirical Results}

Pooled regression model, fixed effects panel regression model and random effects panel regression model are used in the model prediction. The results for every three models are presented in the following table

\begin{tabular}{|l|c|c|c|}
\hline & Pooled OLS & Fixed Effects & Random Effects \\
\hline $\mathrm{c}$ & $\mathbf{2 8 . 7 9 1} * * *$ & $\mathbf{3 6 . 1 7 8} * * *$ & $\mathbf{3 2 . 2 2 1} * * *$ \\
& $(12.94)$ & $(12.92)$ & $(12.12)$ \\
\hline \multirow{2}{*}{ Exports } & $\mathbf{1 . 0 8 6} * * *$ & $\mathbf{0 . 8 5 4} * * *$ & $\mathbf{0 . 9 8 3 * * *}$ \\
& $(19.23)$ & $(10.72)$ & $(14.60)$ \\
\hline Gross Domestic & $\mathbf{- 0 . 9 3 8 * * *}$ & $\mathbf{- 0 . 9 1 7 * * *}$ & $\mathbf{- 0 . 9 4 0 * * *}$ \\
Savings & $(-21.61)$ & $(-16.50)$ & $(-18.97)$ \\
\hline Foreign Direct & $\mathbf{0 . 6 2 5} * * *$ & $\mathbf{0 . 8 8 3} * * *$ & $\mathbf{0 . 7 7 8 * * *}$ \\
Investments & $(6.82)$ & $(8.92)$ & $(8.08)$ \\
\hline F stat & $204.57 * * *$ & $115.58 * * *$ & $444.83 * * *$ \\
\hline
\end{tabular}

Table 1: Effect Of Exports, Gross Domestic Savings and Foreign Direct Investments on Imports Note: Terms on brackets denote $t$-stat based on robust standard errors. *, **, *** indicate significances at the \%10, \%5 and \%1 levels. The coefficients in bold are the ones that are statistically significant.

With respect to the pooled panel regression model, index of exports, gross domestic savings and foreign direct investments is observed to be statistically significant according to the 5\% significance level. According to these results, while one unit of increase in the index of exports increases the imports 1.086 unit, one unit of increase in foreign direct investments leads to a 0.625 unit increase in the imports. One unit of increase in the percentage of gross domestic savings in gross domestic product, however, leads to a -0.938 unit of decrease in imports. Signs of the coefficients are suitable to our financial expectations. When fixed effects panel regression model is predicted, however, coefficients of every three variables are observed to be suitable to our financial expectations as in pooled model and to be significant in 5\% significance level. One unit of increase in the index of exports increases imports about 0.854 unit while one unit of increase in the percentage of domestic savings in gross domestic product decreases the imports 0.917 unit. One unit of increase of the foreign direct investments, on the other hand, increases the imports 0.883 unit.

Finally, random effects panel regression model is predicted. In this model all the coefficients are economically significant. While one unit of increase in the foreign direct investments the imports 0.778 unit, one unit of increase in the exports increases the imports 0.983 unit. One unit of increase in the percentage of gross domestic savings in gross domestic product, however, leads to a 0.940 unit of decrease in imports.

After the coefficients for the three models are interpreted, model comparison is performed. $\mathrm{F}$ test can be applied for the comparison of pooled model and one way fixed effects model. The hypothesis where all the unit effects are equal to zero is tested in F test. To carry out this test, fixed effects model is predicted and F statistics calculated here is compared with the table value. F statistics value obtained here is tested by being compared with $\mathrm{F}$ 
distribution table with $6-1=5$ and $(\mathrm{N}(\mathrm{T}-1)-\mathrm{K})=93$ degree of freedom. According to the obtained $\mathrm{F}(5,93)=10.26$ and Prob $>F=0.0000$ result, the hypothesis that the unit effects are equal to 0 is rejected and thus, it is understood that unit effects are present. Pooled model is not suitable. Hausman test is conducted for the comparison of fixed effects and random effects models. Hausman test results are given in the table. As known, Hausman test shows which of the fixed effects model and random effects model predictors are consistent. Actually in this test the significance of the difference between the fixed effects model parameter predictors and random effects model parameter predictors is examined. The biggest difference between the fixed effects and random effects models is that while unit effects are allowed to be correlated with independent variables in the fixed effects model, this correlation is not at stake and is random in the random effects model. If there is no correlation between the unit effects and explanatory variables, the use of random effects model predictors will be suitable. The main hypothesis of Hausman test is as the following: "No correlation is available between explanatory variables and unit effects" and the alternative hypothesis thereof, however, is as the following: "Explanatory variables and unit effects are correlated".

Test results are given in the Table 2. Zero hypothesis will be rejected according to the Hausman test results. In conclusion, it was determined that fixed effects model predictor is valid for this model.

\begin{tabular}{|c|c|c|c|c|}
\hline & Fixed Effects & $\begin{array}{c}\text { Random } \\
\text { Effects }\end{array}$ & Difference & $\begin{array}{c}\text { Standard } \\
\text { Error }\end{array}$ \\
\hline Exports & 0.85 & 0.98 & -0.13 & 0.042 \\
\hline $\begin{array}{c}\text { Gross Domestic } \\
\text { Savings }\end{array}$ & -0.92 & -.04 & 0.02 & 0.025 \\
\hline $\begin{array}{c}\text { Foreign Direct } \\
\text { Investments }\end{array}$ & 0.88 & 0.77 & 0.11 & 0.023 \\
\hline chi2(3)= & \multicolumn{4}{|c|}{1872.85} \\
\hline Prob $>$ chi2 & \multicolumn{4}{|c|}{0.0000} \\
\hline
\end{tabular}

Table 2: Hausman Test's results

\section{Concluding Remarks}

Macroeconomic variables affecting the imports of Eurasian countries were analyzed in our study. When pool panel regression model, fixed effects and random effects models are predicted, it has been determined exports, foreign direct investments and gross domestic savings variables are statistically significant for every three model. Every three variables are positively correlated with the imports. In conclusion, while export and foreign direct investments variables have a positive effect on the import-dependent variable, the gross domestic savings variable have a negative effect in the 6 Eurasian countries for the 1996-2012 period. We can interpret that import, export and foreign direct investments influencing each other in the same way is the positive result of openness of country economies. We can interpret that negative effect of gross domestic savings on import can have a positive effect on the import for perking up the economies in the region but countries have to develop restrictive politics in the long run for saving aspects

\section{References}

- Hartwell, 2013. "A Eurasian (or a Soviet) Union? Consequences of further economic integration in the Commonwealth of Independent States ", Business Horizons, 56, pp:411-420.

- Kidd, 2007. "The Great Game evolves for Central Asia and opportunities beckon", Management Decision, 45, pp:1224-1251.

- Libman and Vinokurov, 2012. "Regional Integration and Economic Convergence in the Post-Soviet Space: Experience of the Decade of Growth, Journal of Common Market Studies, 50, pp: 112-128.

- Norling and Swanström .2007. "The Virtues and Potential Gains of Continental Trade in Eurasia ", Asian Survey, 47, pp: 351-373.

- Mostafa, 2013. "The concept of 'Eurasia': Kazakhstan’s Eurasian policy and its implications", Journal of Eurasian Studies, 4, pp: 411-420.

- World Bank 2015, Foreign Direct Investments Statistics

- http://data.worldbank.org/indicator/BX.KLT.DINV.WD.GD.ZS

- World Bank 2015, Gross Domestic Savings Statistics

- http://data.worldbank.org/indicator/NY.GDS.TOTL.ZS

- World Bank 2015, Imports Statistics

- $\quad$ http://data.worldbank.org/indicator/NE.IMP.GNFS.ZS

- World Bank 2015, Exports Statistics

- $\quad$ http://data.worldbank.org/indicator/NE.EXP.GNFS.ZS 